\title{
Reducing Radicalism as a Form of Intervention Through the Role of School and Education Curriculum
}

\author{
Didlk Novi Rahmanto $^{1^{*}}$, Adrianus E. Meliata ${ }^{2}$, Ferdinand Andi Lolo ${ }^{3}$ \\ ${ }^{2}$ Department of Criminology, University of Indonesia, Indonesia \\ ${ }^{3}$ Indonesian Prosecutor Commission, Indonesia \\ e-mail: didiknovr2@gmail.com
}

\begin{abstract}
Radicalism become a severe problem for the peace and security of society in Indonesia. So, it is necessary to optimize the role of educational institutions in preventing and offering alternative solutions to the movement of negative radicalism through dialogue and education in schools, from elementary to higher education level. This study aims to examine the role of school and education curriculum as an effort in reducing radicalism. This research is a qualitative study which uses in-depth interviews and literature studies in gathering data. The analysis was carried by using the age graded theory of crime. The results show that school and education curriculum have a role in reducing radicalism. School is a social institution that is very important in each phase of individual growth because schools have a huge role in carrying out positive social values. Therefore, the education curriculum can be arranged in reducing radicalism in society by increasing the portion of cultural values, humanity, tolerance, and the attachment of individuals to their environment.
\end{abstract}

Keywords: Education, Curriculum, Radicalism, Age Graded Theory of Crime

\section{Introduction}

Radicalism poses a severe threat to diversity, peace, and democracy. The term 'radicalism' has emerged since at least the 18th century, which was initially used in the world of medicine and then became a depiction of political attitudes in the late 1790s. This concept spread from the British Revolution after 1688, which progressed to the Enlightenment in France in the 18th century, and reached Germany in the 19th century. In terms of content, radicalism is generally a marker of 'liberal' political principles, liberal to the left-wing, which opposes the establishment of reactionary politics (Sampson \& Laub, 1997; Schmid, 2013). Radicalism became a political doctrine that inspired republican and national movements committed to individual and collective freedom and emancipation, directed against the status quo of monarchies and aristocrats after 1815. Some of the demands in radicalism had become mainstream ideas and were manifested during the century. Political opponents often try to portray radicalism as a subversive, revolutionary force, and now begin to refer to subversive religious forces (Berrebi, 2007; Botticher, 2017; Jacob, 2010).

Furthermore, radicalism is identified as a factor that can directly influence the rise of terrorism. As expressed by (Bjørgo, 2018; Snow \& Cross, 2011) that radicalism is related to micro factors that give rise to terrorism. Most of the research on micro factors are based on the case of individuals who become radical and are involved in terrorist activities. Micro factors are associated with individuals and face-to-face interactions in small groups. Bjorgo and Silke try to understand why and how individuals and groups get radicalized and sometimes even involved in violent activism. In this regard, Bjorgo and Silke found that social ties with radical individuals and groups were how they became involved in militancy and terror activities.

All terrorists, by definition, are radical. Although not all radicals will end up as terrorists, it is clear that most terrorists begin their journey towards violent extremists by becoming radical militants first (Jacob, 2010; Taşpınar, 2009). Because radicalism is often the forerunner of terrorism, focusing on radicalism is the same as preventing terrorism at an early stage, before it is too late for non-coercive measures.

\footnotetext{
${ }^{*}$ Corresponding author.

Received 18 November 2019; Accepted 3 April 2020; Available online 1 September 2020 (C) 2020 JPI. All Rights Reserved
} 
Issues related to radicalism, which have led to violent extremism and terrorism, are a severe concern in various parts of the world. In the Asian context, attention is focused on countries such as Indonesia, Bangladesh, Pakistan, Sri Lanka, Vietnam, and Thailand. Harmony and peace in these areas, which have survived for decades, are now in danger (Infid, 2018).

As mentioned above, Indonesia is currently facing a situation increasing intolerance and the threat of terrorism, which is caused by the development of radicalism. The roots of Islamic radicalism in Indonesia have been present since the early years of independence. However, in development, terrorist groups such as Jemaah Islamiyah (JI) and Jema Ansharu Daula (JAD) are the evolution of the DI / NII struggle to establish an Islamic state through violent means (Infid, 2018). Furthermore, terrorist groups in Indonesia have also announced affiliations with the Islamic State of Syria and Syria (ISIS) (Shoham et al., 2010).

This fact shows that radicalism has genuinely become a severe problem for the peace and security of society in Indonesia (Maghfur \& Muniroh, 2013). With so many and high distribution of narratives of violence and negative radicalism, a counter-narrative is needed for them. This is done by publishing and disseminating narratives that offer values that conflict with violence and radicalism, such as the values of tolerance, diversity, and the four pillars of nationality.

Until last year in Indonesia there were still cases of terror such as a bomb explosion in Kampung Melayu on May 24, 2017, the discovery of explosives in suspected terrorist homes such as those found in Bandung that made the government have to do various ways to overcome the terror that occurred. The head of the Police Public Relations Division Inspector General (Pol) Setyo Wasisto in a discussion in Cikini, Central Jakarta said that in the 2001 period, the Bali Bombing case and up to now more than a thousand suspected terrorists had been arrested and detained. The Director of Communication and Information of the State Intelligence Agency (BIN), Wawan Hari Purwanto, explained in more detail that since 2001, the number of suspected terrorists in the land that died was around 85 people. As many as 37 of them died of their own volition or due to suicide bombings. And the rest died because they resisted the authorities or Detachment 88 (Nursalim, 2014).

These phenomena's, show that the problem of radicalism requires intensive treatment. One of the solutions provided by researchers is through education in schools. The school is an important institution in terms of social control, especially during childhood. Teachers are in a position to monitor children's behavior and disruptive discipline behavior. This is supported by studies that have shown an inverse relationship between school attachment and delinquency in children; increasing school attachment will reduce children's delinquency, and vice versa. Based on previous research, there was an assumption that during childhood, bonding to school would informally control antisocial behavior. School ties consist of excitement at school, achievement at school, and willingness to follow school rules. Referring to the findings of (Fedotova, 2013; Jacob, 2010), of all informal social control institutions, school ties are the most substantial direct protection factor against antisocial behavior in childhood. This supports the hypothesis that ties to schools can reduce antisocial behavior, such as being aggressive, cruel, stealing behavior, disobedience, lying and cheating, and ditching.

The relationship between education and its role in reducing the potential level to become a terrorist. However, (Velias \& Corr, 2017; Y.H.Wong et al., 2019) has developed a theoretical model that shows that terrorist groups' organizations tend to prefer to recruit individuals with better levels of education. But the fact is, individuals who are members of terrorist groups are more likely to come from low economic environments and have limited opportunities to get higher education or opportunities to get better jobs (De Mesquita, 2005).

In 2017, UNESCO published a guideline on how to prevent acts of extremist violence through education. Based on these guidelines, it is mentioned that education service providers or, in this case, schools can provide services with excellent quality teaching and education will create a condition where extremist understandings are challenging to enter and influence someone (UNESCO, 2017). Educational institutions must ensure that the curriculum they use has a positive impact on developing the resilience of students in facing radical ideologies, 
terrorist ideologies, and the concept of violence. For example, educational institutions can develop students' commitment to upholding peace and non-violence.

In addition, educational institutions must also be able to ensure that schools do not become a place for spreading radical ideas to terrorist or extremist groups. United Nations Secretary General Ban Ki-Moon endorsed the 2015 Plan of Action to Prevent Violent Extremism, which places Education, capacity building, and employment as one of the seven areas mentioned as action areas. There are statements as follows,

"As part of the struggle against poverty and social marginalization, we need to ensure that every child receives a quality education which equips him or her for life, as stipulated under the right to education. Education should include teaching respect for human rights and diversity, fostering critical thinking, promoting media and digital literacy, and developing the behavioural and socioemotional skills that can contribute to peaceful coexistence and tolerance." (Plan of Action to Prevent Violent Extremism, 2015)

Based on the statement, the action to be taken is to ensure that all children have access to inclusive and high-quality education, considering a variety of social and cultural backgrounds. In addition, implementing educational programs that promote "global citizenship," soft skills, critical thinking, digital literacy, and explore ways of introducing citizenship education into school curricula, textbooks, and teaching materials. Build the capacity of teachers and educators to support this agenda. Finally, providing comprehensive primary education through tertiary education, including technical and vocational education, and mentoring for all vulnerable people, including refugees, by utilizing online and mobile technology.

The way to improve the effectiveness of education in reducing radicalism, interventions can be carried out in a pedagogical context. Education institution has to priorities socialemotional abilities and behavior of students in order to foster mutual respect and respect for diversity and also a sense of responsibility responsible for the environment.

In this regard, educational institutions become formal institutions that are important to take a role. Given the war on radicalism is a battle of values and is at the level of understanding. (Mahfud et al., 2018) mentioned the need to optimize the role of educational institutions in preventing and offering alternative solutions to the movement of negative radicalism through dialogue and education in schools, from elementary to tertiary level. In essence, early prevention of negative radicalism can be done by strengthening creative, innovative, productive, and cooperative educational activities based on the four pillars of nationalism, namely Pancasila, the 1945 Constitution the Republic of Indonesia, and Bhineka Tunggal Ika (Mahfud et al., 2018).

The threat of radicalization leading to violence indicates that the education system can do more to promote greater social cohesion through the provision of relevant and equitable education of good quality. If schools do not provide students with relevant learning, students will most likely seek answers from unreliable sources of information, which may be manipulated by terrorist groups. This relevant is related to tools and opportunities to determine their future and learn about sensitive issues related to local and global conflicts and tensions) (UNESCO, 2017).

Based on the explanation above, reducing radicalism can be done through schools and educational curricula. Therefore, this research will examine the role of schools and education curriculum in reducing radicalism.

\section{Method}

This type of research used in this research is descriptive research with a qualitative approach. Data collection is done by observation, interview and documentation. Observations in this study were carried out systematically and carried out by looking at the events that took place and analyzing the events directly at the time of the incident when the researcher made observations at the research location. Interview technique is a process of interaction and verbal communication between researchers and research subjects with the aim of getting important information needed, namely by asking a number of questions verbally to be answered verbally. The documentation method is used to search for data in the form of notes, transcripts, books, 
newspapers, magazines, inscriptions, minutes of meetings, agendas and so on that have relevance to the research conducted. The analysis was carried by using the age graded theory of crime.

\section{Result and Discussion}

\section{Result}

\section{Reducing Radicalism Through Cultivating National Character}

Radicalism can emerge anytime, from anywhere and can be done by anyone. Therefore, radicalism needs to be addressed in a comprehensive and comprehensive way. Based on the results of observations, interviews, and documentation that researchers do that reduce radicalism can be done through the inculcation of national character. The cultivation of national character includes: 1) introducing the symbol of the State of Indonesia and obliging to memorize the contents of Pancasila, 2) instilling the values of the national spirit of exemplary heroes, 3) recognizing and memorizing regional and national songs, 4) conducting ceremonial activities every Mondays and ceremonies on national holidays, 5) scout extracurricular activities.

The contents of the values contained in the national character instilled through some of these activities should have been introduced to children in school since they were still in elementary school and their existence should have always been maintained. The activity of introducing the symbol of the state and memorizing the contents of the Pancasila is important for students because to introduce them to the symbol of the country and to understand the contents of the Pancasila which reflects the different Indonesian people but remains one and not easily divided. Based on the results of interviews conducted by researchers, the activity of instilling the values of the national spirit of the exemplary heroes is carried out by the teacher by telling stories of the heroes' struggles. So that later students will be able to reap positive things and the spirit of the heroes striving to liberate the Indonesian people.

The activity of recognizing and memorizing folk songs is carried out to provide knowledge and learning to students that Indonesia is a country rich in ethnicity and culture so that we must be able to respect one another so that it is not easily divided. Ceremonial activities every Monday and ceremonies on national holidays are held to commemorate the services of the heroes and to reward the services of the heroes. In addition, students can practice discipline and student responsibility. Scout extracurricular activities carried out to form student character. The main task of the Scouting Movement in particular to develop the character of discipline is to organize scouting education for Indonesian children and youth, to seek the goals of the Scouting Movement so that it can form development cadres who are Pancasila-minded and capable and able to carry out community, nation and state development.

\section{Reducing Radicalism Through the Upholding of Morality Systems}

Based on observations, interviews and documentation that researchers do, that the thing done to reduce radicalism is through the enforcement of morality. The development of education oriented to upholding morality can be done by developing: democratic values, developing citizenship life, community values, developing clean government, forming national identity, developing social ties and diversity including tolerance, social justice and the development of personal life and the development of family values. Education that shapes personality and character begins with the upholding of ethics and morals in self, family, school and society.

Strengthening moral education that is applied in schools is very effective in being able to shape a child's morals into an intelligent and wise person in facing challenges. Moral formation is carried out to develop democratic values such as holding class meetings, electing class leaders, respecting the opinions of different friends. So that when they grow up, they will be able to develop democratic values in a greater space. 


\section{Reducing Radicalism Through Tolerance Learning Systems}

Based on the results of observations, interviews, and documentation that researchers do that what is done to reduce radicalism is through a tolerance learning system. Education is organized in a democratic and non-discriminatory manner by upholding human rights, religious values, cultural values, and national plurality. Thus, the purpose of education can realize harmony and tolerance. Harmony will be realized if tolerance develops. Tolerance development is characterized by respecting the opinions of others, being friendly without discriminating between tribes and religions, mutual respect, controlling emotions, not mocking friends, designing and doing various social activities, respecting school officials, helping each other, visiting friends who are sick, and mourn if a parent die. The process of fostering tolerance and social care for students is carried out through classroom learning, extracurricular activities, and habituation in the school environment

Religious intolerance is dangerous because it gives an opportunity for the emergence of radicalism. Security and tranquility are threatened, because followers of radicalism are usually intolerant and even willing to kill others. So that the inculcation of the value of tolerance in children is very important, especially in schools to foster mutual respect and respect among students. Implanting knowledge to students that the difference is actually unique and beautiful. Tolerance learning is the basis for students so that one day they can create a peaceful and harmonious life. So that later there will be no conflict or even no understanding of radicalism because students from an early age already understand that Indonesia is a multicultural country.

\section{Discussion}

Reducing radicalism can be done through several things, including through the planting of national character, morality enforcement systems, and tolerance learning systems. The discussion in this study is as follows.

\section{Reducing Radicalism Through Cultivating National Character}

The activity of planting national character which is carried out routinely can reduce radicalism. The activity of introducing the symbol of the State of Indonesia and the obligation to memorize the contents of the Pancasila is done so that students know and understand the contents of the symbol of the State of Indonesia so that later it can be implemented well. Besides that, the values of the spirit of nationalism are instilled from the example of the heroes through their struggle stories so that students can set an example from the heroes who have struggled to liberate the Indonesian state. Students are also required to memorize national and regional songs as part of the character learning program. National songs are also given on SBK (Art and Culture) subjects. By knowing national stories and songs, it is hoped that it can foster a sense of love for students in these schools for the Indonesian homeland. Ceremonies every Monday and national holidays are routinely conducted and each student is obliged to attend except for reasons that can be accounted for. This is useful for fostering nationalism and valuing the services of heroes. Scout extracurricular activities are going well. Every Friday afternoon students are required to attend Scouting activities at school. Scout activities include understanding scouting material, marching, apple layout and ceremonies and group dynamics. In this Scouting activity, students are taught about patriotism and nationalism, which is one of the important points in the Dasa Dharma Pramuka.

These activities can foster national character that exists in students so that students have a sense of patriotism and nationalism. As the theory revealed by (Hibban, 2016; Mulyadi, 2017 ) the indicators of nationalism attitude among others are self-sacrifice, prioritizing unity and unity, love for the motherland, and a reformer spirit and do not know surrender. This is also supported by Hertz's theory which states that the general characteristic of nationalism is the process of becoming the only nation. These indicators can be grown through activities introducing the symbol of the State of Indonesia and must memorize the contents of Pancasila, instilling the values of the national spirit of exemplary heroes, knowing and memorizing regional and national songs, performing ceremony activities every Monday and ceremonies on national holidays, scout extracurricular activities. Research conducted by (Satriawan et al., 2019) 
focuses on efforts to prevent radicalism through the inculcation of the Pancasila ideology and the culture of community-based constitutional awareness. These preventive activities are a form of defending good citizens in order to maintain the survival of the nation and the whole nation by preventing radicalism in each community.

\section{Reducing Radicalism Through the Upholding of Morality Systems}

The development of education oriented to upholding morality can be done by developing: democratic values, developing citizenship life, community values, developing clean government, forming national identity, developing social ties and diversity including tolerance, social justice and the development of personal life and the development of family values. These activities can reduce radicalism because these activities develop moral values so that students have instilled morality. This is useful so that they become moral individuals.

Strengthening moral education that is applied in schools is very effective in being able to shape a child's morals into an intelligent and wise person in facing challenges. Moral formation is done to develop democratic values such as: conducting class deliberations, electing class leaders, respecting the opinions of different friends. Class deliberations are one way to develop democratic values. Class discussion is held to discuss the problems faced by the class. so that later in making a decision, attempted through deliberation. Class leader election activities can also develop democratic values. The election of class leaders can be done by deliberation or by voting (voting). Appreciating the opinions of different friends can also develop democratic values so that students do not feel selfish and assume their opinions are the most correct. These three activities can make students later develop democratic values in a greater scope when they are adults. In addition, understanding democratic values to students can also be done through Civics Education. Like the research conducted by (Christopel \& Kuntoro, 2016) the application of inquiry methods can improve students' understanding of democratic values at Gamping 1 Sleman High School.

\section{Reducing Radicalism Through Tolerance Learning Systems}

Tolerance learning is characterized by respecting the opinions of others, being friendly without discriminating between tribes and religions, mutual respect, controlling emotions, not mocking friends, designing and doing various social activities, respecting school officials, helping each other, visiting friends who are sick, and mourn if a parent die. The process of fostering tolerance and social care for students is carried out through classroom learning, extracurricular activities, and habituation in the school environment. Students are helped to accept, acknowledge, and appreciate socio-cultural diversity or diversity, political aspirations, and economic capabilities. By accepting each other, different people can complement and help one another. The human rights of everyone are recognized and the uniqueness of each group is recognized, even developed. An attitude of mutual acceptance and respect will quickly develop if it is trained and educated on students in the national education system. With this education, students are trained and made aware of the importance of respect for others, and other cultures, and even train them in life so that when they grow up they already have that attitude. So, the importance of developing an attitude of tolerance and togetherness through pedagogical engineering in the background of a plural society. In the school environment, students interact with each other, learn to respect differences, and accept one another, which is possible in an environment that he has never encountered.

Religious intolerance is dangerous because it gives an opportunity for the emergence of radicalism. Security and tranquility are threatened, because followers of radicalism are usually intolerant and even willing to kill others. So that the inculcation of the value of tolerance in children is very important, especially in schools to foster mutual respect and respect among students. Implanting knowledge to students that the difference is actually unique and beautiful. Tolerance learning is the basis for students so that one day they can create a peaceful and harmonious life. So that later there will be no conflict or even no understanding of radicalism because students from an early age already understand that Indonesia is a multicultural country. Tolerance is an absolute necessity in social life. As research conducted by (Faridah, 
2013) that housing communities are of the view that religion and beliefs are their personal affairs where there is an awareness of mutual respect and an agreement not to disturb the beliefs of others.

\section{Conclusion}

Based on the data collected and the analysis conducted by researchers, it can be concluded that reducing radicalism can be done through Cultivating National Character include: introducing the symbol of the State of Indonesia and obliging to memorize the contents of Pancasila; instilling the values of the national spirit of exemplary heroes; recognizing and memorizing regional and national songs; conducting ceremonial activities every Mondays and ceremonies on national holidays; scout extracurricular activities, Upholding of Morality Systems including tolerance, social justice and the development of personal life and the development of family values. Education that shapes personality and character begins with the upholding of ethics and morals in self, family, school and society, Tolerance Learning Systems including respecting the opinions of others, being friendly without discriminating between tribes and religions, mutual respect, controlling emotions, not mocking friends, designing and doing various social activities, respecting school officials, helping each other, visiting friends who are sick, and mourn if a parent die.

\section{References}

Berrebi, C. (2007). Evidence About the Link Between Education, Poverty and Terrorism Among Palestinians. Peace Economics, Peace Science and Public Policy, 13(1), 18-53. https://doi.org/10.2202/1554-8597.1101

Bjørgo, T. (2018). Routledge Handbook of Terrorism and Counterterrorism (A. Silke (ed.)). Routledge.

Botticher, A. (2017). Towards Acedemics Consensus Definition of Radicalism and Extremism. $\begin{array}{llll}\text { Perspectives on 11(4), T3-77. } & \text { Terrorism, }\end{array}$ http://www.terrorismanalysts.com/pt/index.php/pot/article/view/623/html

Christopel, C., \& Kuntoro, S. A. (2016). Pemahaman nilai-nilai demokrasi siswa melalui metode inquiri pada pembelajaran Pkn di SMA Negeri 1 Gamping Sleman. Harmoni Sosial. Jurnal Pendidikan IPS, 3(1), 14-26. https://doi.org/10.21831/hsjpi.v3i1.9697

De Mesquita, E. B. (2005). The Quality of Terror. American Journal of Political Science, 49(3), 515-530. https://doi.org/10.1111/j.1540-5907.2005.00139.x

Faridah, I. F. (2013). Toleransi Antarumat Beragama Masyarakat Perumahan. Komunitas: International Journal of Indonesian Society and Culture, 5(1), 14-25. https://doi.org/10.15294/komunitas.v5i1.2368

Fedotova, O. (2013). Radicalism and Terrorism Problems in a Scientific Discourse of Russian Social Sciences. Procedia - Social and Behavioral Sciences, 334-343. https://doi.org/10.1016/j.sbspro.2013.08.681

Hibban, I. (2016). Radikalisme Agama Dalam Kajian Sosiologi. Jurnal Sosiologi Reflektif, 9(1), 219-223. https://conference.uin-suka.ac.id/isoshum/sosiologireflektif/article/view/1128

Infid. (2018). A Cross-Country Report on Trends of Extrimism in South and South-East Asia. International NGO Forum on Indonesian Development.

Jacob, J. C. (2010). Pathways of Crime and Delinquency: A life-course Analysis of Informal Social Control of Antisocial Behaviour. University of Waterloo.

Maghfur, M., \& Muniroh, S. M. (2013). Women Behind Terrorists (Religiousity, Self Adaptation and Husband-Wife Relationship within Suspected Terrorists Family in Pekalongan). Analisa: Journal of Social Science and Religion, 20(2), 181-195. https://doi.org/10.18784/analisa.v20i2.175

Mahfud, C., Prasetyawati, N., Wahyuddin, W., Muhibbin, Z., Agustin, D. S. Y., \& Sukmawati, 
H. (2018). Religious Radicalism, Global Terrorism and Islamic Challenges in Contemporary Indonesia. Jurnal Sosial Humaniora (JSH), 11(1), 8-18. https://doi.org/10.12962/j24433527.v11i1.3550

Mulyadi, M. (2017). Peran Pemuda dalam Mencegah Paham Radikalisme. Prosiding Seminar Nasional Program Pascasarjana Universitas PGRI Palembang, 248-255. https://jurnal.univpgri-palembang.ac.id/index.php/Prosidingpps/article/view/1457

Nursalim, M. (2014). Deradikalisasi Terorisme: Studi Atas Epistemologi, Model Interpretasi dan Manipulasi Pelaku Teror. Kalam : Jurnal Studis Agama Dan Pemikiran Islam, 8(2), 329-346. https://doi.org/10.24042/klm.v8i2.230

Sampson, R. J., \& Laub, J. H. (1997). A life-course theory of cumulative disadvantage and the stability of delinquency. Developmental Theories of Crime and Delinquency, 7(1), 133161.

Satriawan, I., Islami, M. N., \& Lailam, T. (2019). Pencegahan Gerakan Radikalisme Melalui Penanaman Ideologi Pancasila dan Budaya Sadar Konstitusi Berbasis Komunitas. Jurnal Surya Masyarakat, 1(2), 99-110. https://doi.org/10.26714/jsm.1.2.2019

Schmid, A. P. (2013). Radicalisation, De-Radicalisation, Counter-Radicalisation: Conceptual Discussion and Literature Review. International Centre for Counter-Terrorism.

Shoham, S. G., Knepper, P., \& Kett, M. (2010). International Handbook of Criminology. CRC Press.

Snow, D. A., \& Cross, R. (2011). Radicalism Within the Context of Social Movements: Processes and Types. Journal of Strategic Security, 4(4), 115-130. https://www.jstor.org/stable/26463914?seq=1\#metadata_info_tab_contents

Taşpınar, Ö. (2009). Fighting Radicalism, Not" Terrorism": Root Causes of an International Actor Redefined. SAIS Review of International Affairs, 29(2), 75-86. https://doi.org/10.1353/sais.0.0059

UNESCO. (2017). Preventing Violent Extrimism through Education: A Guidefor Policy-Makers. UNESCO.

Velias, A., \& Corr, P. (2017). Effects of terrorism threat on economic preferences: The role of personality. Contemporary Voices: St Andrews Journal of International Relations, 8(2), 62-72. https://jtr.st-andrews.ac.uk/article/10.15664/jtr.1305/

Y.H.Wong, M., VinodKhiatanib, P., \& HongChui, W. (2019). Understanding Youth Activism and Radicalism: Chinese Values and Socialization. The Social Science Journal, 56(2), 255267. https://doi.org/10.1016/j.soscij.2018.08.006 